present; but taling these five cases, $T 0$ ses three bives suved that would otherwise have been lost. The reeults of all the operations performed during the past fifteen months in London, shew Inther more than one out of two successful ; and $I$ have no doubt that when the diagnosis of this disease is more perfect; when the operation is performed earlier; when all the steps of the operation are carefully done; when health is improved by diet and medicine before operstion; and when the after treatment is thoroughly understood-then, and not till then, must we expect to be able to lay down any table of com. parison. Let us, however, be encouraged by the experience of herniotomy, lithotomy, and lithotrity, and the more recent amputations of the thigh ; and, observing how improred treat. ment has told upon their statistics, let us confidently anticipate that surgery will yet triumph in ovariotomy, and thus benefit hamanity.

17, Connaught Square, Hyde Park, May 1859.

\section{REMARKS ON DR. INMAN'S PAPER "ON THE INFLUENCE OE VITALITY UPON} SEORETION".

By Jonk Kext Spender, Esq., Surgeon to the Eastern Dispensary, Bath.

I HAve read with considerable interest Dr. Inman's paper in the Joursar of April 30th, "On the Influence of Vitality upon "Secretion". His observations embody much that has probably occurred to the thoughtful physiologist, though perhaps never before put into 80 intelligible and practical a form. But the ques. tion is at once suggested: Is not Dr. Inman confonnding two essentially different processes-active and passive secretion? $A c$. tive secretion is a sign and product of life, and is coincident with the activity of all the other organic processes. Pastive secre. tion is almost entirely physical act, and is independent of nerve-power: nay, it even goes on better when nerve-power is diminished or suspended. It scarcely deserves the name of vital function at all; but $I$ apprehend that it pretty accurately defines that phenomenon of which Dr. Inman has given so many appropriate illustrations.

In true secretion, we have three elements to bear in mindthe blood from which the secretion originally comes; the blood-vessel through which the secretion transudes; and the gland-struoture which is the anatomical instrument for separating and eliminating it. Now, the most ultimate gland structure always possesses the several constituents of mucous membrane; namely, areolar tissue, basement-membrane, and epithelial cells; and the special characters of the different secretions are usually said to depend upon the elective faculty with which these epithelial cells are endowed.

Active secretion being an index of present life and force, the epithelial cells are busy in the work; but the term passive secretion literally expresses the fact that the aqueous portion of the blood, and very little else, simply filters through the blood-vessels and gland-walls; and that vital agency has very little to do with it. For example, increased outaneous perspiration is of two kinds-active, when it accompanies bodily exercise; passive, when it is the effoct of exhausting diseases, and the prelude of death itself. In the former case, it is the symbol of angmented finction; in the latter, it is merely that the diminished tone of the capillary walls allows the water of the blood to permeate them. Paralysis of the vasi-motor nerves, or any particular dyscrasia, produces the same result. I lately attended a case wich illustrates this point. A child of seven years old had threatening mesenteric disease : her gkin was cold and dry by day, and covered with profuse passive sweat at night. By alterative and tonic medicines, and a regulated diet, constitutional improvement quickly ensued, and the passive 87 eat was stopped; and, in the course of a few weeks, the skin was constanuly moistened with the warm dew of active perspiration.

A so-called diuretic drug may appear to exercise a marked effect in increasing the amount of urine; and, if the organic and inorgenic principles of this socretion are increased in proportion to the aqueous constituent, it is a true instence of accelerated functional activity. But, in bysterical and nerrous persons, who pass a large quantity of nearly colourless urine at a time, the haste with which the water filters through the Malpighian tufts leaves scarcely any time for it to be im. pregnated with the contents of the epithelial cells that line the ariniferous tubes, and which are the agents for imparting to 412 the urine its special oharacters. The act is loss a vital the physical one, and cannot with precision be termed a secreton process at all.

Pathology supplies us with numerous fucts illwatrative of the same distinction. The primary stoges of bronohorthoen, gonorrhces, and diarrhos, have partioular features in common; and the exudative products of these forms of loow inflamma $s$ tion have analogous appearances and qualities; but, if these in- $\vec{\sigma}$ flammations beoome chronic in duration or asthenio in degres, the byperæmia in which thes severally originated is unnaturally $\frac{\sigma}{\bar{N}}$ prolonged, and this local blood-stasis causes a corresponding $\frac{\sigma}{T}$ change in the nature of the exudations.

It is an old doctrine, that secretion is only form of mole. cular nutrition; the tissne nourished being the epithelial cells, and the nutriment supplied to them that which is ultimately $\rightarrow$ destined to be the secretion itself. This being granted, wo have a right to assume that the influence of innervation is much required for the formation and growth of glend-cells $n \vec{\omega}$ for the ultimate elements of every other animal tissne. Con sequently, when nerve-force is lessened, gland-cells camno $\frac{O}{3}$ form and grow so rapidly, and the secretional product must bo diminished in an equal ratio. Hence, whenever we have an is apparently augmented secretion as the accompaniment or $\frac{1}{-}$ result of weakened power, we ought to regard it, not as an ex.-. altation of a physiological act, but rather as a retrogression $N$ into the domain of purely physical processes.

\section{ON TNUNITED RRACTURT}

By W. J. Moore, Esq., H.M. Indian Medical Service, Bombay Establishment ; formerly Senior Resident Surgeon at the Queen's Hospital, Birmingham.

Urress there be some constitutional cause, either already per. sistent, or the result of circumstances, as. locality, situation diet, etc., immediately after the accident, it will seldom happen that Nature's reparutive process is insufficient to consolidate sO fractured limb, treated with ordinary care both by attendanf and patient. When such non-consolidation does happen, is must always be regarded as a grave and serious occurrence, ano the more so the nearer the trunk it may be situated. Thuse both as regards the inconvenience to the patient, and the diffis culty and dangers attending attempts at cure or relief, the bones of the forearm or leg will give more anxiety to the suro geon than those of the foot or hand; and, again, in their turn, the tibia, ulna, and radius, are less a cause for nneasiness than when the femur or humerus is the bone affected. This remarf is not only true regarding operative attempts at cure, but applies with double force to those unfortunate cases where thes state of the limb requires amputation as a dernier ressort.

The bones in which false joints most frequently occur are of according to the statistics collected by Mr. Norris, those of the thigh and arm (American Journal of the Medical Sciences, rop xxix, 1842); but my own experience rould lead me to infe? that the occurrence took place at least as frequently in the bones of the forearm us in those of any other part of the frame. South (Chelius, p. 888) states that unnatural jointe are most frequent in the upper arm; nezt, the femur would appear to be the one generally affected; and the tibia seem least liable to such result. This is, indeed, what one would, priori, suppose to be the case, as it is evident that a brokes. leg can be kept in perfect apposition with greater ease and ap curity than a broken thigh; and thus one source of unnaturat joint does not act with the same frequency an the formet part.

The causes of non-union of broken bones, and of unnatur and false joints, are numerous; but foremost may be meip tioned a debilitated or cachectic condition of system. Sin Astley Cooper, in his work On Fractures and Dislocations, ${ }_{0}$ 568, observes: "In numerous instances, the failure of vion may be traced to a defective state of the constitutional porrers 'This debility may arise from divers causes, such as bad foods habitual loss of blood, as from hæmorrhoids; residence in the impure localities or underground tenements of crowded citif Malarious atmosphere will also produce condition in whige union is with difficulty obtained. This was exemplifted in the case of a sailor under my oare, when in medical charge of th naval station of Bassadore, in the Persian Gulf, where the disposition to non-union was happily combated by a lengthen course of quinine and wine.

- For an account of Baseadore, we a paper by the author "On th Climate of the Persian Gulr", Association Medical Joumal, Novenber lowe 